\title{
High School Students' Attitudes to Engineering and Engineers related to their Career Choice
}

\section{Mrs. Adriana Anunciatto Depieri, University of Sao Paulo}

For almost 10 years I have worked as an assintant professor and since 2003, I have worked for the Brazilian Ministry of Science, Technology and innovation in the Popularization of Science and Technology issues. Besides policy formulation and implementation of programs to popularize $S \& T$, we give support to improve science teaching in schools, in partnership with the Ministry of Education. Authorized by deads, I have dedicated most of time as a $\mathrm{PhD}$ candidate at the University of Sao Paulo for the last two years in the area of Enginnering.

\section{Prof. Roseli de Deus Lopes P.E., Escola Politécnica, Universidade de São Paulo}

ROSELI DE DEUS LOPES. Associate Professor at the Electronic Systems Engineering Department, Escola Politécnica, Universidade de São Paulo (EP-USP). She received the undergraduate, master, doctorate and post-doctorate degrees in Electrical Engineering from EP-USP. She is the vice-chair of the Instrumentation Center of Interactive Tecnologies at USP (CITI-USP). She was vice-chair (2006-2008) and director (2008-feb.2010) of Estação Ciência, a Center for Scientific, Technological and Cultural Dissemination of USP. She is a researcher at the Laboratório de Sistemas Integráveis (LSI) of EP-USP since 1988, where she is a principal investigator of the Interactive Electronic Media research group (which includes research in computer graphics, digital image processing, techniques and devices for human-computer interaction, virtual reality and augmented reality). She coordinates research projects in the area of Interactive Electronic Media, with emphasis on applications related to Education and Health. She coordinates scientific dissemination initiatives and projects aimed at identifying and developing talents in Science and Engineering. She was responsible for the design and feasibility of Febrace (Brazilian Fair of Science and Engineering), the biggest national pre-college science and enginnering fair in Brazil. Since 2003, she acts as the general coordinator of Febrace. She is the current academic coordinator of the "USP e as Profissões" (USP and Careers) program at USP. She is a member of the working group of technical and educational support for the program of One Computer per Student (UCA - um computador por aluno), sponsored by the Ministery of Education. She is a member of the deliberative council of the USP Museum of Sciences. 


\section{High School Students' Attitudes to Engineering and Engineers related to their Career Choice (Research-to-practice)}

Strand: other

\section{INTRODUCTION}

There is a continuous worldwide need to increase the number of skilled engineering graduates in order to improve economic competitiveness and to facilitate societal evolution. Therefore, increasingly inspiring young people to choose careers in engineering can be a path to avoid discrepancy between the number of qualified university graduates and the number of job openings in the future, not only in Brazil but all over the world.

In the last ten years, the number of universities' engineering courses and enrollments in all regions of the country showed a $12 \%$ average growth per year between 2001 and $2011^{38}$. However, in comparison to all university major areas, only $5 \%$ of Brazil's undergraduate students major in engineering compared with $6 \%$ in the U.S., $12 \%$ in Europe, $20 \%$ in Singapore, and $40 \%$ in China ${ }^{19,41}$. Figure 1 shows Brazil's position in an Organization for Economic Co-operation and Development (OCED) international comparison of engineering degree holders per 10,000 inhabitants in 2011, in which Brazil is far beyond more developed countries $^{38,46}$.

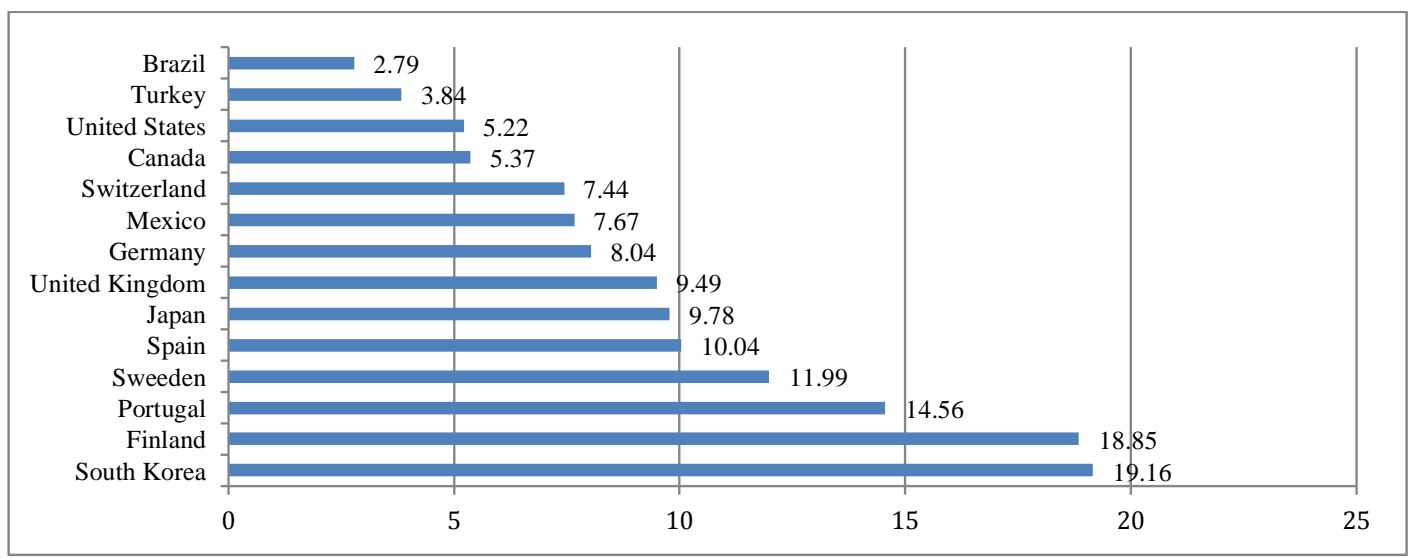

Figure 1: Number of Engineers per 10,000 inhabitants in some OECD Countries in $2011^{46}$.

However, this scenario may change in a few more years due to the increasing numbers of Brazilian engineering undergraduate students lately, where in 2012 this number had a significantly percentage of growth probably due to recent Brazilian educational policies changes ${ }^{46}$. And the number of masters' degrees and $\mathrm{PhDs}$ graduated in all field areas by Brazilian universities has more than quadrupled in the last 15 years, jumping from 13,219 in 1996 to 55,047 in $2011^{11}$. Figure 2 shows the evolution of doctoral and master's degrees in engineering from 2001 to 2011. Nevertheless, this growth was not enough to place Brazil among countries with large contribution to engineering research yet, as from 2001 to 2005, Brazil contributed with only $1.4 \%$ of world engineering research against United States'28.1\%'s, Japan's $10.3 \%$ and China's $8.6 \%^{41}$. With regard to scientific production and taking the BRIC countries production as a whole, China is emerging with the biggest contribution coming in 2012 to be responsible for about $85 \%$ of the publications, India takes the second place with $8 \%$, Russia holds $4 \%$, and finally Brazil, with $3 \%$ of publications in engineering ${ }^{46}$. 
In order to increase the number of student pursuing engineering degrees, it is important to raise interest in STEM (Science, Technology, Engineering and Mathematics) education and to encourage and motivate more adolescent students to pursue careers in engineering ${ }^{12}$. Engineering undergraduate students, undergoing a curriculum with a strong mathematical and logical content-oriented problem solving, may be more well prepared in the sense of "learning to learn"42. But the essence of future education is to provide students with the development of new required professional competencies for a new changing world.

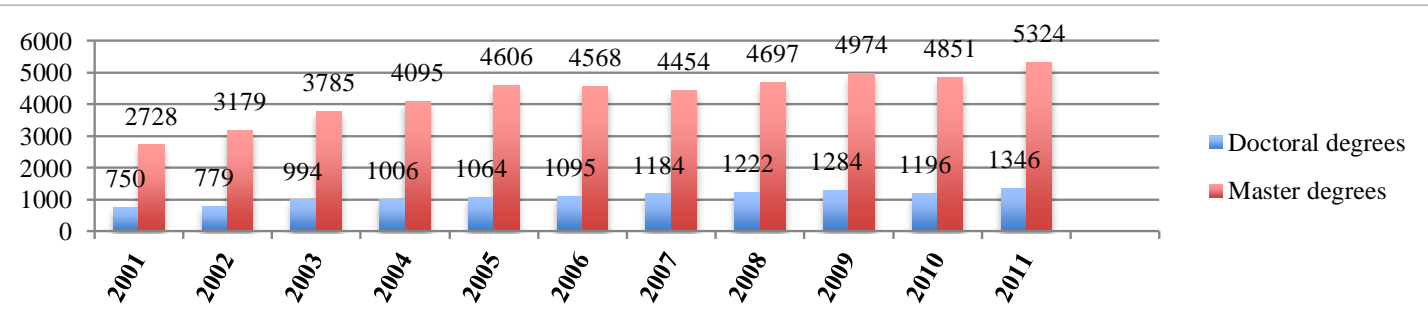

Figure 2: Numbers of obtained Brazilian doctorals and masters' degrees in Engineering from 2001 to $2012^{11}$.

As any other country, Brazilian engineering education has faced a double challenge: to educate citizens to live within a rapidly changing world and to train professionals to meet the demand of a changing labor market ${ }^{12}$. Under these circumstances, students must be increasingly motivated and prepared in high school to provide society with not only more but better engineering students and professionals.

Brazilian weak results at Program for International Student Assessment's (PISA) ${ }^{11}$ reinforces the fact that the teaching of STEM subjects in high schools must be improved since these subjects are closely related to the development of the next generation of engineers. Students more interested in STEM subjects may be one positive inclination towards science, technology, engineering and mathematics fields. More qualified engineers will enhance competitiveness in the global economy and improve the workforce's ability to address technical and technological issues ${ }^{21}$. Additionally, high school students must learn the "21st century skills" which include problem solving, critical thinking, and media literacy to prepare for the new global, digital economy ${ }^{39}$.

Added to the well-known relevance of science and mathematics for the development of engineers, there are many other student entry-level attitudes that may affect their level of interest and motivation to pursue engineering courses and careers. We believe that more knowledge of engineering and engineers' daily life can favorably shift the attitudes of high school students towards engineering ${ }^{18,20,36}$; however, this lack of knowledge may be moving students away from the engineering profession. This leads to the necessity to enhance the number of engineering activities in the existing high school curriculum in order to be more effective in promoting positive attitudes towards engineering.

Even though there are some initiatives to foster engineering and technological literacy among children such as the Engineering is Elementary (EiE) project at Boston's Science Museum that aims to foster engineering and technological literacy among children, standards for desired and/or required "K-12 engineering skills", are not widely recognized. However, K-12 education principles could be applied to existing high school subjects in order to improve not 
only engineering but more professional students' attitudes. Based on Katehi ${ }^{21}$, K-12 education should: 1) emphasize engineering design, the approach engineers use to identify and solve problems; 2) incorporate important and developmentally appropriate mathematics, science, and technology knowledge and skills; and 3) promote engineering habits of mind, including systems thinking, creativity, optimism, collaboration, communication, and attention to ethical considerations.

According to $\mathrm{OECD}^{31}$, differences in young people's career choice can be attributed to traditional perceptions of gender roles and identities as well as the wide acceptance of cultural values associated with particular fields of education. Therefore, high school students' attitudes to engineering may be an important predictor of not only being adequately prepared to engineering but its pursuit. If more high school students acquire positive attitudes towards engineering, more of them will be motivated to choose engineering as a career.

An attitude is a relatively enduring organization of beliefs, feelings, and behavioral tendency towards socially significant objects, groups, events or symbols ${ }^{43}$. In other words, an attitude is an expression of favor or disfavor toward a person, place, thing, or event, and this psychological tendency is expressed by evaluating a particular entity with some degree of favor or disfavor ${ }^{13}$ usually through a likert scale as a direct attitude measurement ${ }^{24}$.

Besides being measurable and changeable as well as influencing the person's emotion and behavior, attitudes can be formed from a person's past and present ${ }^{1}$. Therefore, based on a familiar cliché "positive attitudes produce positive results", we believe that high school students' positive engineering attitudes may produce positive results in terms of the intentions to pursue Engineering studies.

Engineering attitudes have been widely documented through the literature $7,10,18,28,29$ since they have the power to attract or to repel students from STEM studies ${ }^{27}$. However, research on engineering attitudes rarely focuses on how students perceive engineering related to their intended career or choice of university major.

Although attitudes of freshman engineering students change over the course of their first academic year affected by the type and quality of educational program that the students' experience ${ }^{7}$, we think it is important to consider attitudes that students bring to the university. Therefore, this research aims to provide a Brazilian baseline measure of high school students' attitude to engineering which could be taken forward and used to inform educational action plans and also to improve students' engagement in engineering.

This paper presents a study that addresses the issue of Brazilian high school students' attitudes to engineering and engineers, and how these relate to their intention of majoring in engineering at university level courses. And we hypothesized that students' attitudes to engineering and engineers were significantly more positive when directly related to their interest in pursuing a career in engineering.

\section{METHOD}

As the most straightforward way of finding out about someone's attitudes would be to ask him/her, a direct attitude measurement was conducted by using a six-point-likert scale (totally agree, partially agree, indifferent, partially disagree, totally disagree, I don't know). It was used in this research, since this is the most widely used approach to scaling responses in 
survey researches. Our engineering attitudinal survey was not only concerned with whether a high school student thinks positively or negatively about the topic, but also how powerful the feeling is for the student.

Based on well-known literature $2,4,5,6,7,8,9,10,15,17,18,23,28,29,37$ an attitudinal scale student survey was developed in order to determine if high school students' attitudes to engineering and engineers differ between students who do consider engineering as a career (group 1- DO) and students that do not consider engineering as a career (group 2- DO NOT).

As survey validity can be increased through pilot testing with the intended audience ${ }^{14,22,44}$, a pre-test was applied to one male 16-year-old high school student. He was told to be free to ask any question or make any comment while answering the pre-test. Some adjustments were done to the survey and a test-retest measure of reliability ${ }^{44}$ was obtained by administering the same instrument to the same individual at a different point in time. The degree to which both administrations are in agreement is a measure of the reliability of the instrument ${ }^{44}$. Then, the same pre-test was applied to six high school students ( 5 female and 1 male) in order to count how much time they would spend in filling out the survey and also to register their comments. In future studies, more instrument validation techniques may be conducted to reassure that the survey is measuring what it was designed to measure ${ }^{14,40,44}$. The final version of survey after all adjustments were made can be seen in figure 5 .

Students were asked to complete a paper-based questionnaire during a career fair, called "USP and The Professions", at the University of São Paulo (USP) main campus. It is a threeday event in which students come from all over the state of São Paulo to get information about all the major and other opportunities that are offered at USP, besides participating in hands-on activities, campus tour, conversations, lectures, and other activities.

For this paper, the survey structure consisted of three parts: participants' profile (age, gender, type of school, kind of course and class year), evaluated questions (47 six-point likert-type scale items) and engineering choice or not. Figure 3, shows the identification part (part 1).

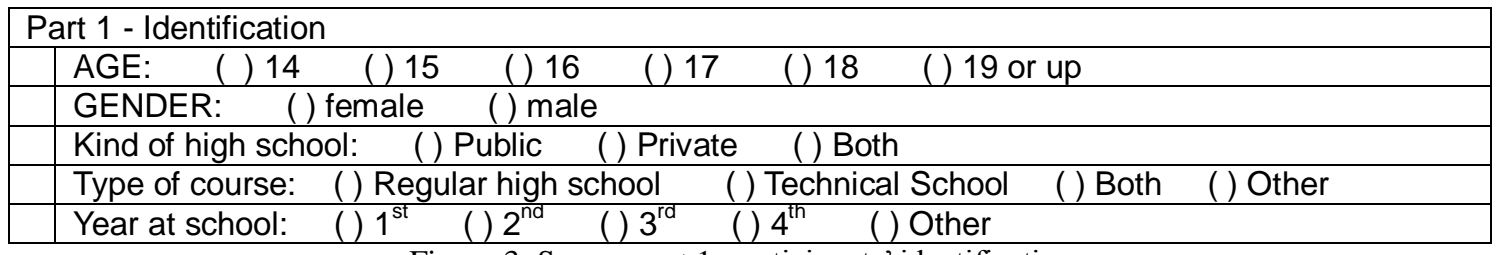

Figure 3: Survey part 1: participants' identification.

We collected 510 completed, paper-based questionnaires, digitalized and analyzed the data. Throughout the analysis process, care was taken in the organization and interpretation of the data to ensure transferability, dependability, and conformability. From the 510 surveys, two surveys were discarded because their ages were out of our research age range. Figure 4 shows distribution and characteristics of the 508-sample.

When considering the type of school students go to, the "both" option refers to some schools classified to be both public and private in Brazil. They are usually part of the private school network, although free for students, but maintained by a foundation, and considered as a philanthropic nonprofit school. 
The regular Brazilian high school educational system consists of three years: first, second and third. Some schools offer a four-year vocational track that is equivalent to secondary education given at regular high school, with added technical training in specific areas such as mechanics, electronics, chemistry, etc. Some students do have the opportunity to take both tracks at the same time, in separate shifts. This is the reason why there is "both" as an option to mark under the type of course they are at. The option "other" refers to special classes for students who already graduated from high school, for example preparatory courses for university entrance exams.

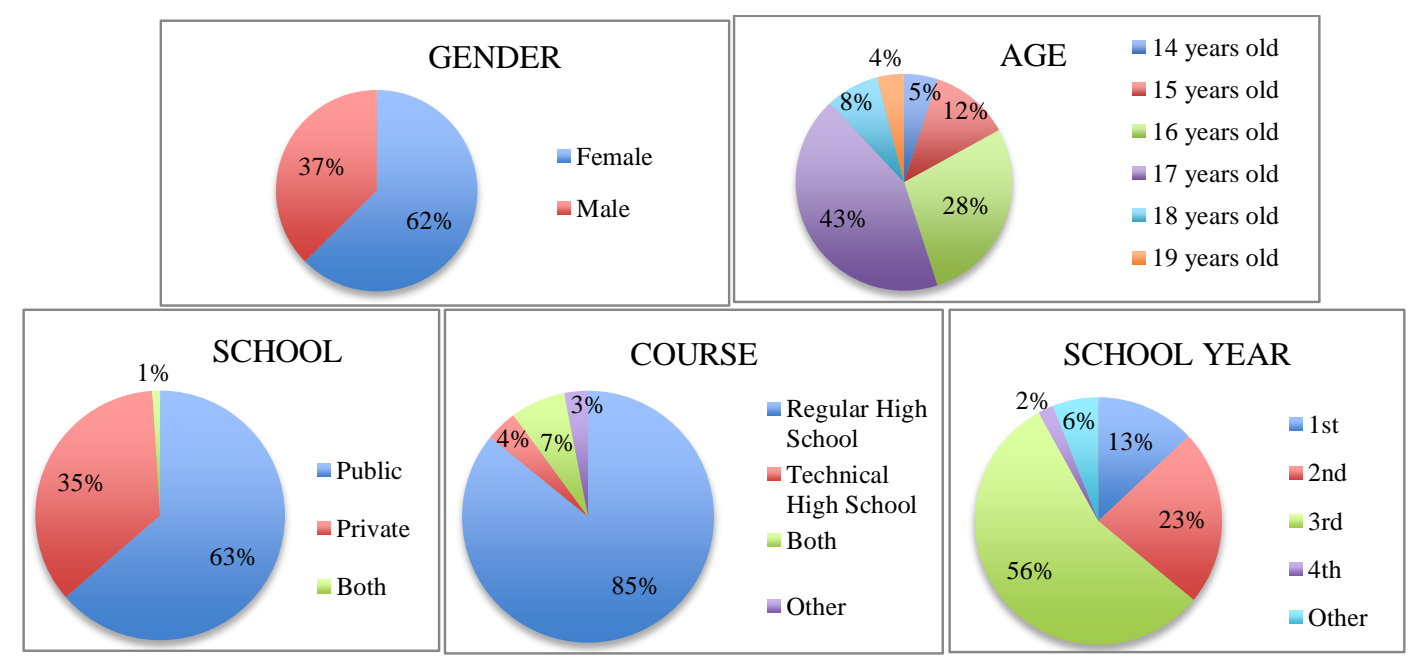

Figure 4: Sample characteristics of the 508 high school survey participants.

In order to attract students to complete our survey, a poster was displayed stating "Do you want to win a tablet? We want to know what you think... so answer a survey for a chance to win a tablet!" After completing the survey, each participant filled out a separate sheet of paper (used for the tablet run), containing his or her name, e-mail address and contact phone number, since the survey had no space for any personal information, maintaining confidentiality.

\section{RESULTS AND ANALYSIS}

Data analysis was conducted in order to determine if high school students' attitudes towards engineering differ in terms of students' age, gender, type of school, kind of school (course) and year they study at. Techniques used in this study included a quantitative method of descriptive statistics analysis of the survey; categorizing themes using analysis matrix, and cross-case analysis.

Overall survey results demonstrated that high school students' attitudes to engineering are positive, as shown in figure 5. For each survey item, positive and negative attitudes were taken into consideration. Positive attitudes were given by the sum of "totally agree" and answers (TA+PA), Group A, marked by high school students' responses. While negative attitudes, were given by the sum of "partially disagree" and "totally disagree" answers (PD+TD), Group B.

Note that negative attitudes related to the survey items 36, 37, 38, 41, 42, 43 and 44 in which (PD+TD) columns (red) present higher scores than (TA+PA) columns (blue), is caused by negatively phrased sentences about engineering and engineers. Therefore, the parameters of 
negative attitudes shown in the graph (figure 5) mean, in fact, higher positive attitudes towards engineering and engineers.

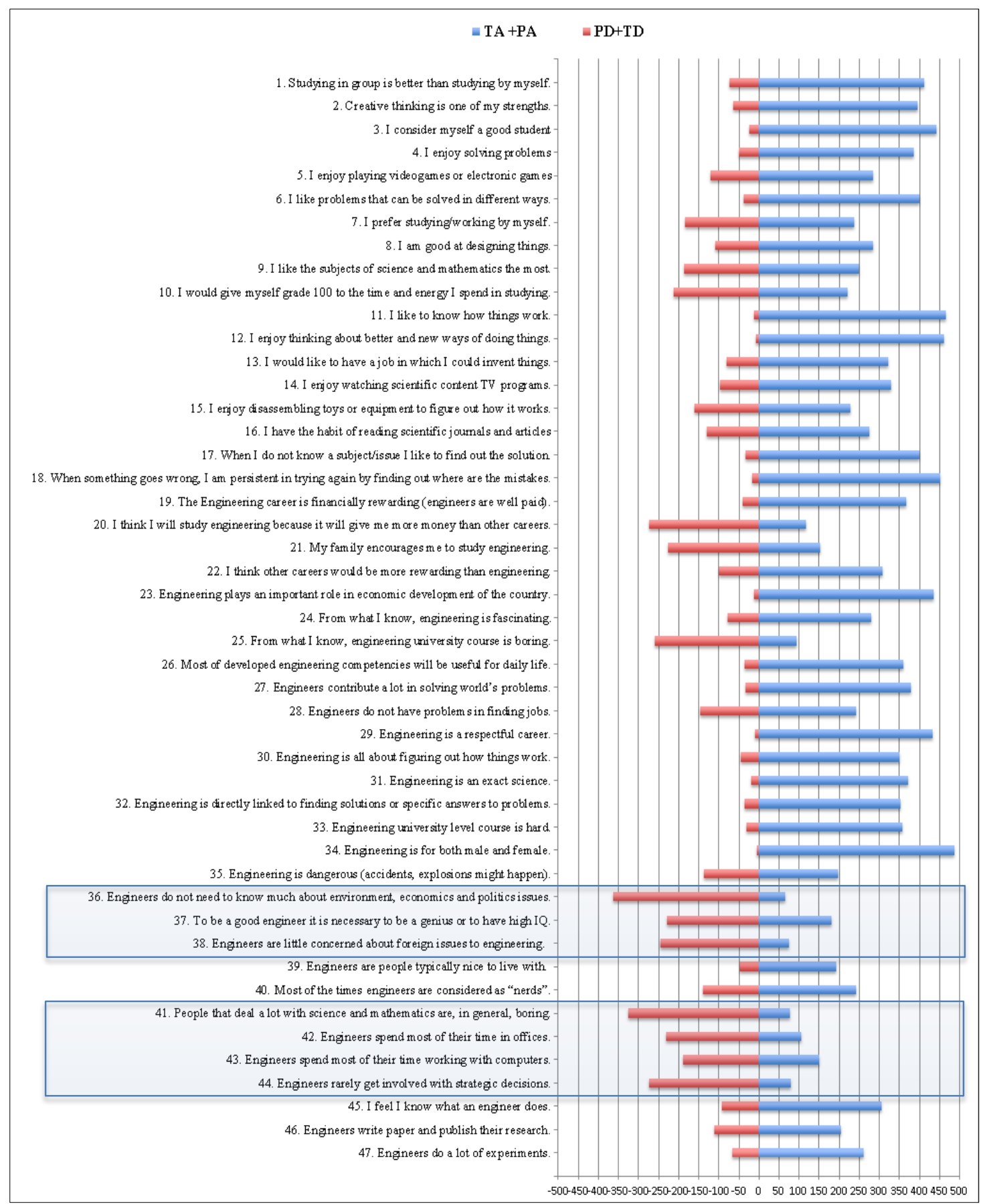

Figure 5: Sum of answers considering two groups. Group A (blue), sum of totally agree (TA) and partially agree (PA) answers. Group B (red), sum of partially disagree (PD) and totally disagree (TD) answers.

\section{Pearson Correlation Tests}

Pearson correlation coefficient values range from +1 to -1 . Pearson correlation tests were applied to the survey results, demonstrating that there is limited correlation since all values were very close to zero, in which a zero value indicates no association between each of the 
two variables. Results demonstrate positive and negative correlations according to the participants' gender, school, course and age, and results are shown in figure 6 . The numbers from 1 to 47 refer to the survey items.

The colors in Pearson correlation (figure 6) tests indicate that the more reddish the more closer to -1 correlation coefficient, while the greener the closer to +1 correlation coefficient. Overall results from the Pearson test are shown in the figures below.

\begin{tabular}{|c|c|c|c|c|c|c|c|c|c|c|c|c|c|c|c|c|c|c|c|c|c|c|c|c|}
\hline & 1 & 2 & 3 & 4 & 5 & 6 & r & 0 & 9 & 10 & 11 & 12 & 13 & 14 & 15 & 16 & 17 & 18 & 19 & 20 & 21 & 22 & 23 & \\
\hline In & ,07 &, 06 & ,06 & 0,03 & 0,31 & 0,06 & 04 & 09 & 0,18 & 0,07 & 0,05 & $-0,02$ & 17 & 0,23 & 0,31 & 0,09 & 0,01 & 0,03 & 0,06 & 0,16 & 0,22 & 0,11 & $-0,03$ & \\
\hline ho & 0,25 & ,11 & $-0,16$ & 0,00 & 0,06 & $-0,01$ & 0,14 & 0,01 & 0,10 & $-0,14$ & $-0,08$ & $-0,08$ & $-0,08$ & $-0,02$ & $-0,03$ & $-0,06$ & $-0,13$ & $-0,07$ & $-0,07$ & 0,02 & $-0,05$ & $-0,11$ & 0,06 & \\
\hline 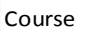 & 0,03 & 0,04 & 0,05 & 0,01 & $-0,04$ & 0,05 & 04 & 07 & 0,03 & 0,09 & 08 & 0,00 & ,06 & .02 & 0,06 & 0,03 & ,07 & 1,05 & 09 & 0,01 & 0,08 & 05 & 07 & \\
\hline \multirow[t]{2}{*}{ Age } & 0,03 & 0,05 & 0,00 & 0,02 & 0,05 & $-0,04$ & $-0,04$ & $-0,06$ & $-0,03$ & $-0,01$ & $-0,04$ & 0,03 & $-0,02$ & 0,08 & 01 & 0,03 & ,04 & 02 & $-0,01$ & $-0,01$ & $-0,06$ & 0,01 & $-0,05$ & \\
\hline & 2 & 2 & 26 & 2 & 28 & 29 & $3 c$ & 3 & 3 & 33 & 34 & 35 & 36 & 37 & 38 & 39 & 40 & 41 & 12 & 43 & 44 & 45 & 46 & \\
\hline Gen & 0,10 & ,02 & 0,01 & 0,04 & $-0,04$ & 0,00 & 04 & , ,00 & 0,05 & 03 & $-0,06$ & 0,03 & 01 & ,04 & 0,10 & 0,02 & 0,09 & 02 & 0,12 & 16 & 0,07 & 13 & 14 & 0,0 \\
\hline chool & $-0,09$ & 0,09 & $-0,01$ & 0,05 & $-0,06$ & $-0,03$ & 0,00 &, 11 & 0,07 & & 0,01 & 0,0 & & 0,01 & 0,02 & 0,04 & ,03 & 0,04 & 0,08 & ,12 & 0,07 & 55 & 04 &, 1 \\
\hline Course & 0,05 & $-0,02$ & 0,00 & 0,05 & $-0,02$ & 0,01 & ,01 & 0,04 & 0,02 & 0,04 & 0,00 & $-0,07$ & 0,03 & $-0,03$ & 0,02 & 0,04 & 0,04 & 00 & $-0,05$ & $-0,09$ & 0,00 & $-0,07$ & 00 & $-0,0$ \\
\hline ge & 0,06 & 0,06 & 0,01 & $-0,02$ & 0,00 & $-0,01$ & 0,11 & 0,05 & 0,13 & 0,01 & $-0,05$ & $-0,03$ & $-0,06$ & $-0,15$ & 0,00 & $-0,08$ & 0,05 & 0,00 & $-0,01$ & $-0,01$ & $-0,07$ & $-0,08$ & 0,00 & $-0,0$ \\
\hline
\end{tabular}

Figure 6: Pearson correlation test results.

Considering participants' gender, there is a higher positive correlation in questions 5 (I like playing video games or electronic games) and 15 (I enjoy disassembling toys or equipment to verify how it works), while in question 22 ("I think other careers would be more rewarding than engineering") a higher negative correlation is shown. This means that, for those questions we have the highest differences between female and male.

In terms of the kind of schools, there is a positive correlation in items 7 ("I prefer studying or working alone") and 47 ("engineers do a lot of experiments") and a negative correlation in item 1 ("group studying is better than individual one"). This shows that there is a small difference between students from public and private students for those statements. In relation to the type of course participants take (regular, technical/vocational high school or others), the results for Pearson correlation tests were not significant.

In terms of age correlation results, item 32 ("engineering is directly related to finding problems precise answers or solutions to") showed a positive correlation, but a negative one in item 37 ("to be a good engineer it is necessary to be a genius and/or have a high IQ"). This means that, for those questions we have the highest differences among students, as they get older.

Based on students' responses, one finding which could appear to be contradictory to our initial hypothesis (that students' attitudes to engineering and engineers were significantly more positive when directly related to their engineering career choice) was that, except for a few items, the questionnaires data analysis show that students' attitudes to engineering did not differ significantly between the two groups, group 1 (students that consider engineering as a career) and group 2 (students that do not consider engineering as a career option). Figure 7 shows Pearson correlation tests for group 1, and figure 8 shows group 2 results. Group 1 and group 2 descriptive results are summarized on tables 1 and 2, respectively.

So, as the correlation coefficients were very low, the results show that there is almost no significantly variation among participants' answers, considering gender, school type, course type and age, demonstrating that for the students of our sample of Brazilian high school students, they do have positive attitudes towards engineering no matter if they do or do not consider engineering as a career choice. 


\begin{tabular}{|l|r|r|r|r|r|r|r|r|r|r|r|r|r|r|r|r|r|r|r|r|r|r|r|r|r|}
\hline & 1 & 2 & 3 & 4 & 5 & 6 & 7 & 8 & 9 & 10 & 11 & 12 & 13 & 14 & 15 & 16 & 17 & 18 & 19 & 20 & 21 & 22 & 23 & \\
\hline Gender & $-0,10$ & 0,06 & $-0,05$ & 0,00 & 0,34 & 0,01 & 0,05 & 0,04 & 0,17 & $-0,09$ & 0,08 & $-0,03$ & 0,12 & 0,22 & 0,30 & 0,06 & 0,00 & $-0,07$ & $-0,09$ & 0,16 & 0,17 & $-0,15$ & $-0,01$ & \\
\hline School & $-0,29$ & $-0,07$ & $-0,11$ & 0,01 & 0,04 & $-0,07$ & 0,17 & 0,06 & 0,12 & $-0,12$ & $-0,07$ & $-0,08$ & $-0,01$ & 0,00 & $-0,05$ & $-0,09$ & $-0,16$ & $-0,12$ & $-0,11$ & 0,04 & $-0,02$ & $-0,10$ & 0,05 & \\
\hline Course & 0,02 & $-0,08$ & 0,02 & 0,01 & $-0,04$ & 0,03 & 0,02 & $-0,11$ & $-0,02$ & 0,09 & 0,08 & 0,00 & $-0,08$ & 0,00 & 0,04 & 0,01 & 0,05 & 0,02 & 0,10 & $-0,05$ & 0,03 & 0,06 & 0,08 & \\
\hline Age & 0,04 & 0,08 & 0,05 & 0,11 & 0,07 & 0,02 & $-0,05$ & 0,00 & 0,01 & 0,06 & 0,00 & 0,01 & $-0,03$ & 0,12 & 0,08 & 0,12 & 0,08 & 0,05 & 0,02 & 0,03 & $-0,03$ & $-0,03$ & $-0,05$ & \\
\hline & 24 & 25 & 26 & 27 & 28 & 29 & 30 & 31 & 32 & 33 & 34 & 35 & 36 & 37 & 38 & 39 & 40 & 41 & 42 & 43 & 44 & 45 & 46 & 47 \\
\hline Gender & 0,08 & 0,00 & $-0,01$ & 0,05 & $-0,07$ & $-0,01$ & 0,07 & 0,03 & 0,03 & $-0,02$ & $-0,05$ & 0,09 & 0,02 & $-0,04$ & 0,11 & 0,00 & $-0,10$ & 0,05 & 0,15 & 0,20 & 0,04 & 0,15 & 0,12 & 0,01 \\
\hline School & $-0,14$ & 0,03 & $-0,06$ & 0,03 & $-0,09$ & $-0,03$ & $-0,01$ & 0,07 & 0,04 & $-0,01$ & 0,02 & 0,04 & $-0,02$ & $-0,06$ & 0,07 & 0,05 & 0,02 & $-0,05$ & 0,14 & 0,15 & 0,13 & 0,03 & 0,04 & 0,12 \\
\hline Course & 0,03 & 0,01 & 0,04 & 0,06 & $-0,02$ & $-0,01$ & 0,02 & 0,05 & 0,03 & 0,04 & $-0,01$ & $-0,06$ & 0,05 & $-0,06$ & $-0,01$ & 0,03 & 0,04 & $-0,02$ & $-0,06$ & $-0,11$ & $-0,05$ & $-0,12$ & 0,00 & $-0,05$ \\
\hline Age & 0,13 & 0,00 & 0,07 & $-0,03$ & 0,05 & 0,03 & 0,14 & 0,08 & 0,14 & 0,02 & $-0,07$ & $-0,04$ & $-0,04$ & $-0,16$ & 0,00 & $-0,06$ & 0,11 & 0,04 & 0,02 & 0,02 & $-0,04$ & $-0,05$ & 0,06 & 0,06 \\
\hline
\end{tabular}

Figure 7: Pearson correlation tests results for the group of students that DO consider engineering as a career option (group 1- DO).

\begin{tabular}{|l|r|r|r|r|r|r|r|r|r|r|r|r|r|r|r|r|r|r|r|r|r|r|r|r|}
\hline & 1 & 2 & 3 & 4 & 5 & 6 & 7 & 8 & 9 & 10 & 11 & 12 & 13 & 14 & 15 & 16 & 17 & 18 & 19 & 20 & 21 & 22 & 23 & \\
\hline Gender & $-0,02$ & 0,06 & $-0,11$ & 0,08 & 0,18 & 0,09 & 0,00 & 0,19 & 0,13 & $-0,10$ & $-0,06$ & 0,07 & 0,24 & 0,23 & 0,27 & 0,18 & $-0,01$ & 0,02 & $-0,08$ & $-0,08$ & 0,24 & 0,07 & $-0,12$ & \\
\hline School & $-0,17$ & $-0,26$ & $-0,27$ & $-0,06$ & 0,15 & 0,06 & 0,04 & $-0,15$ & 0,07 & $-0,18$ & $-0,07$ & $-0,08$ & $-0,21$ & $-0,05$ & 0,00 & 0,07 & $-0,06$ & 0,00 & 0,08 & 0,01 & $-0,08$ & $-0,16$ & 0,09 & \\
\hline Course & 0,04 & 0,09 & 0,15 & $-0,05$ & $-0,11$ & 0,01 & 0,14 & 0,09 & 0,07 & 0,01 & 0,08 & 0,04 & $-0,03$ & 0,01 & 0,09 & 0,04 & 0,12 & 0,09 & 0,00 & 0,01 & 0,07 & 0,04 & 0,05 & \\
\hline Age & 0,04 & $-0,03$ & $-0,11$ & $-0,17$ & 0,05 & $-0,11$ & $-0,04$ & $-0,17$ & $-0,04$ & $-0,12$ & $-0,10$ & 0,09 & 0,07 & 0,02 & $-0,10$ & $-0,13$ & $-0,07$ & 0,00 & $-0,03$ & 0,03 & $-0,01$ & $-0,04$ & $-0,03$ & \\
\hline & 24 & 25 & 26 & 27 & 28 & 29 & 30 & 31 & 32 & 33 & 34 & 35 & 36 & 37 & 38 & 39 & 40 & 41 & 42 & 43 & 44 & 45 & 46 & 47 \\
\hline Gender & 0,02 & 0,03 & $-0,01$ & $-0,02$ & $-0,01$ & $-0,05$ & $-0,11$ & $-0,12$ & 0,04 & $-0,11$ & $-0,13$ & $-0,17$ & $-0,05$ & $-0,04$ & 0,03 & $-0,02$ & $-0,10$ & $-0,06$ & 0,01 & 0,05 & 0,08 & 0,02 & 0,19 & 0,09 \\
\hline School & 0,08 & 0,17 & 0,07 & 0,08 & 0,03 & 0,03 & 0,04 & 0,21 & 0,15 & 0,08 & $-0,03$ & 0,06 & 0,02 & 0,16 & $-0,11$ & $-0,01$ & 0,11 & 0,00 & $-0,01$ & 0,12 & $-0,08$ & 0,17 & 0,06 & 0,29 \\
\hline Course & 0,00 & $-0,01$ & $-0,19$ & $-0,01$ & $-0,07$ & $-0,01$ & $-0,11$ & 0,04 & $-0,08$ & 0,01 & $-0,04$ & $-0,13$ & $-0,03$ & 0,00 & 0,05 & 0,00 & 0,03 & 0,03 & $-0,09$ & $-0,11$ & 0,06 & 0,02 & $-0,05$ & $-0,05$ \\
\hline Age & $-0,02$ & 0,14 & $-0,06$ & 0,04 & $-0,09$ & $-0,05$ & 0,07 & 0,01 & 0,18 & 0,04 & 0,01 & 0,03 & $-0,09$ & $-0,09$ & 0,01 & $-0,08$ & $-0,07$ & $-0,07$ & $-0,03$ & $-0,05$ & $-0,10$ & $-0,10$ & $-0,15$ & $-0,19$ \\
\hline
\end{tabular}

Figure 8: Pearson correlation tests results for the group of students that DO NOT consider engineering as a career option (group 2- DO NOT).

Question-to-question correlations were also made in order to observe tendencies between groups 1 and 2. Although Group 1 and Group 2 correlation results shown in figures 11 and 12 are hard to see due to the size of Excel sheet, it is possible to identify just a few reddish spots which would indicate a strong correlation.

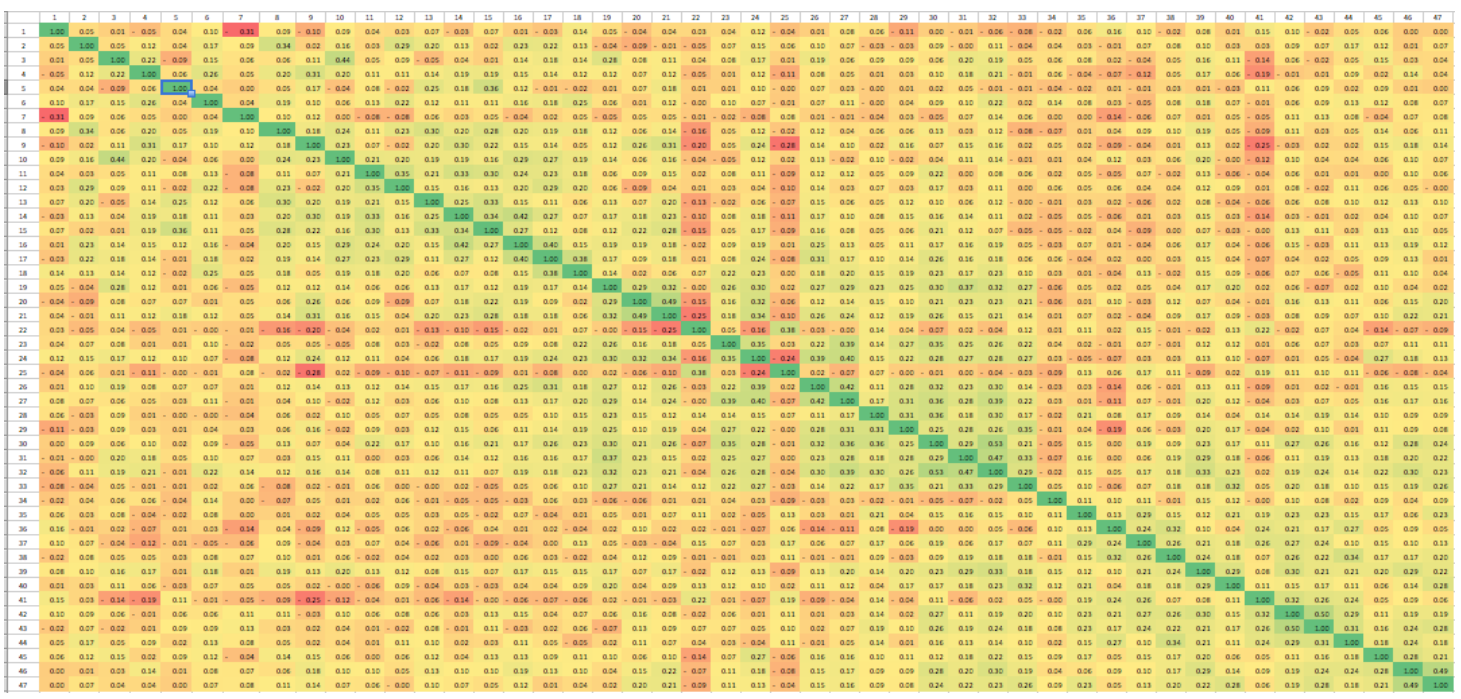

Figure 11: Excel sheet print screen of Group 1- DO - Pearson questions correlations.

To further illustrate this question-to-question correlation, survey items 23 (ecology/ environmental sciences) and 24 (group work/ group studies) will be more thoroughly described. Positive correlations in items 23 and 24 were identified when paired with survey items 2 and 8, 3 and 10, 4 and 9, since results demonstrate that all those correlations are bigger than 0.30 . This means that most students that consider engineering as a career do not know or totally disagree with item 24 , they also do not know or totally disagree with item 23 . And most of Group 1 students that totally or partially agree with 23 , they totally or partially agree with 24 . 
Negative question-to-question correlations identified were in items 7 and 1,9 and 22, 9 and 25, 9 and 41, 21 and 22, 24 and 25. Most students that consider engineering as a career do not know or totally disagree with item 24 , they totally or partially agree with 23 . And students that do not know or totally disagree with 23, they totally or partially agree with 24 .

Group 2 Positive correlations between 24 and 23 demonstrate that all correlations are bigger than 0.30. Most students that do not consider engineering as a career do not know or totally disagree with item 24 , they also do not know or totally disagree with item 23 . And most of Group 1 students that totally or partially agree with 23 , they totally or partially agree with 24 .

Negative correlations demonstrated correlations more negative than -0.30 between 24 and 23 . Most students that do not consider engineering as a career do not know or totally disagree with item 24 , they totally or partially agree with 23 . And students that do not know or totally disagree with 23 , they totally or partially agree with 24 .

Other correlation coefficients are being tested in order to find more sensitive to nonlinear relationships.

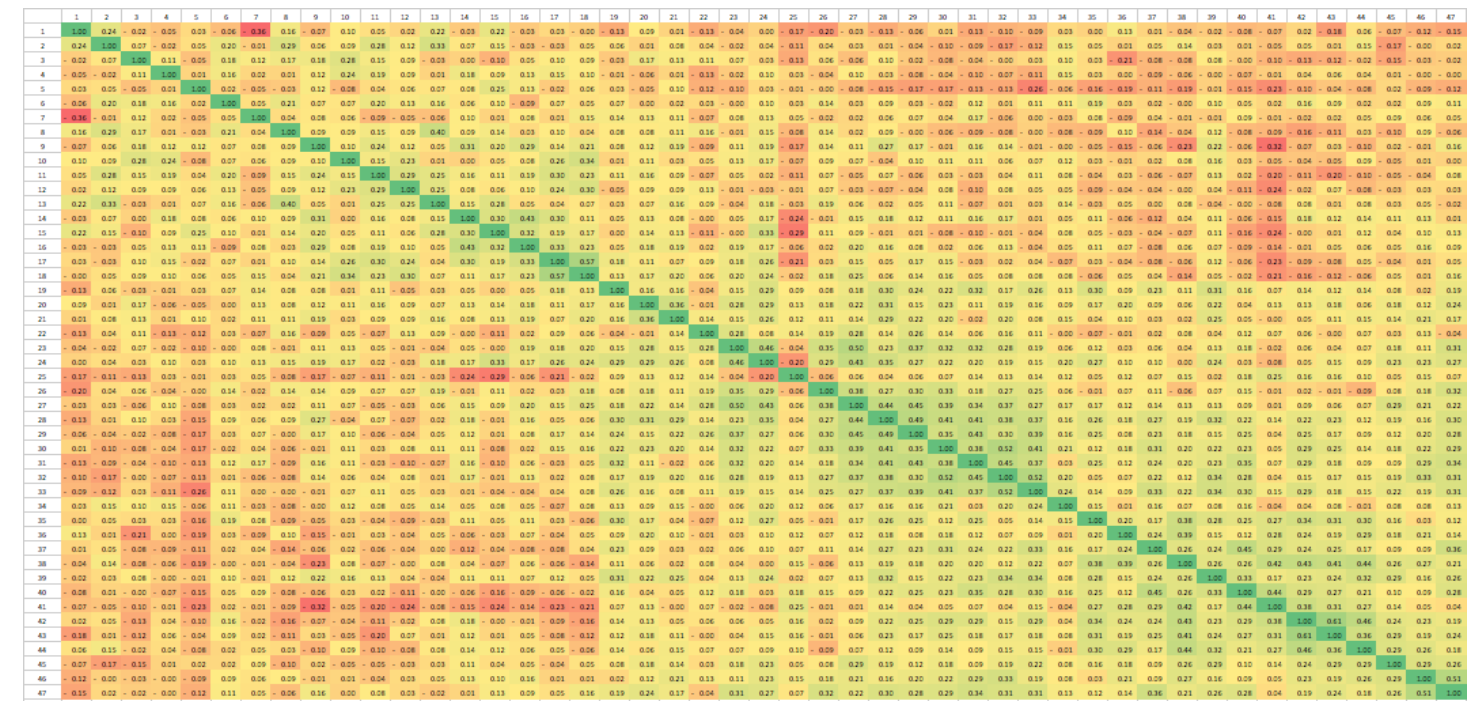

Figure 12: Excel sheet print screen of Group 2 - DO NOT - Pearson question-to-question correlations.

Pivot tables

Pivot tables and graphs were used to summarize, analyze, explore and present data for each survey item by correlating answers of Groups 1 and 2. Graphs generated provided information of items with more and less positive / negative attitudes. Except for a few survey items, overall responses were essentially contained no noteworthy differences between the two groups, since they vary less than $10 \%$ to each other, except for items $22,24,26,45$ and 47. These five survey items showed a difference of more than $10 \%$ variation between groups 1 and 2 answers.

Items 3,11, 12, 18, 23, 29 and 34 showed more positive attitudes since these seven survey items answers had the highest scores, when considering the sum of "totally agree" and "partially agree" options marked by both groups 1 and 2 (figure 5). But following the same criteria (considering the sum of "totally agree" and "partially agree" options marked by both 
groups 1 and 2), items $25,38,41$ and 44 showed more negative attitudes since this sum do not reach $20 \%$ of their answers.

Items 36, 41 and 44 had the more negative attitude by adding scores of "partially disagree" and "totally disagree" options marked by both groups 1 and 2 are considerably high. And with the same sum criteria, items 11, 12, 23, 29, 31 and 34 had lowest scores for it. Above all, the most positive attitude was noticed in item 34 for both groups 1 and 2 (figure 13), while the most negative attitude was for item 36 (figure 14).

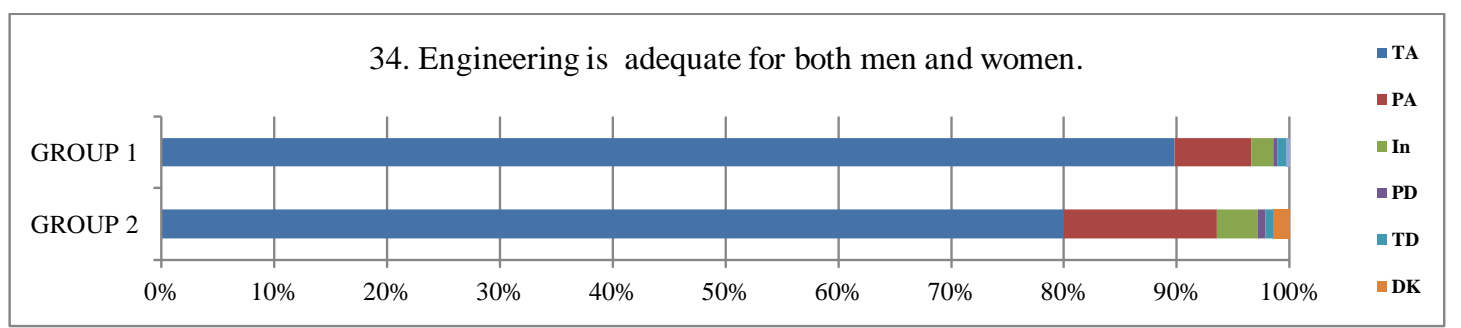

Figure 13: Chart from pivot table considering Groups 1 and 2 answers to survey item 34 . TA=totally agree; PA= partially agree; $\mathrm{IN}=$ Indifferent; $\mathrm{PD}=$ partially disagree; $\mathrm{TD}=$ totally disagree; $\mathrm{DK}=\mathrm{I}$ don't know.

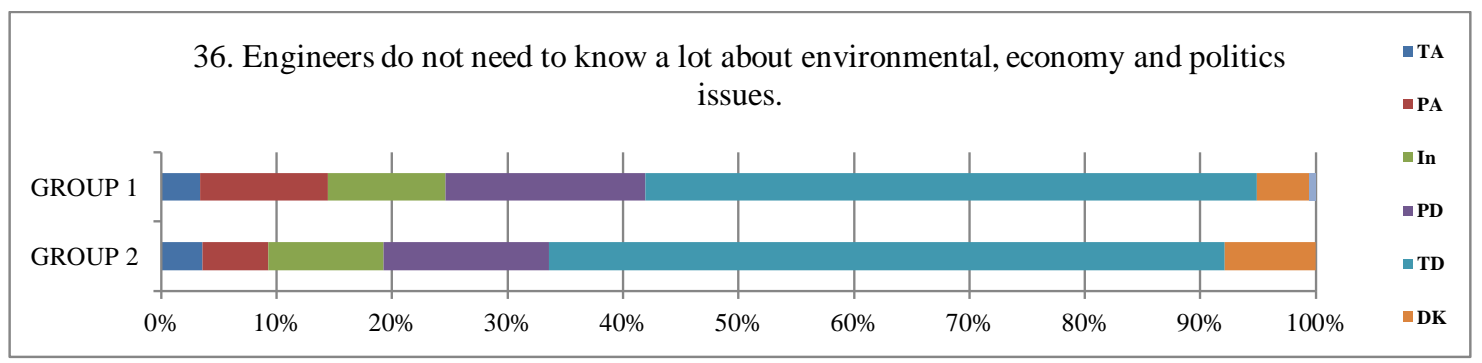

Figure 14: Chart from pivot table considering Groups 1 and 2 answers to survey item 36. TA=totally agree; PA= partially agree; $\mathrm{IN}=$ Indifferent; $\mathrm{PD}=$ partially disagree; $\mathrm{TD}=$ totally disagree; $\mathrm{DK}=\mathrm{I}$ don't know.

However, when comparing some personal likes or abilities (items 4, 6, 8, 9, 11, 12, 15), Brazilian students' general attitudes towards engineering are all almost not dependent on their engineering choice or not, even with slight statistically differences. And except for items 7, 12, 17 and 41 that their positive answers to them show almost no difference at all when comparing the two groups, all of the other items responses show higher Group 1 positive attitudes than group 2 ones.

Students' positive attitudes to how engineers contribute to society (items 23 and 27) differ in the total sum of positive and negative attitudes (figure 5), but show almost the same range of statistical difference related to Group 1 and 2 answers. On average, engineering was perceived as making a good contribution to society besides being involved with several important issues affecting society today. However, Brazilian students show more positive attitudes towards the importance of engineering to the country's economic development than to solving world problems.

\section{DISCUSSIONS AND CONCLUSIONS}

In Brazil and some other parts of the world, high school students are required to make a career choice very early in life and when they are very young for such an important decision. Although it is not easy to decide whether or not the career chosen will suit him or her for a 
lifetime, many successful people take time to slowly work out what it is that makes them tick and brings them fulfillment.

No matter what the career choice is selected, students need to start planning in high school to ensure they are prepared to take the correct major later at university. Some specific profile tests may help as a starting point for students to gain a better understanding of their interests, values and goals, alongside discussions with friends, family or professional career counselors at school or elsewhere. Good career decisions require good information about personal traits and preferences, and also about the real world and workforce.

When considering engineering as a career choice, excelling in mathematics and additional related subjects such as chemistry, physics or higher math subjects will surely benefit the candidate. And results for students' like of science and math more than other subjects (survey item 9) corroborates to this since the group of students that consider taking engineering do have positive attitudes related to liking science and math better than other high school subjects. Moreover, it is not easy to decide whether engineering is the right career choice, but having more positive attitudes towards engineering - and towards other areas is no different may be a path to help or enable students to take up the right career decision.

It is challenging to educate an engineer prepared to meet the challenges encountered in this new century, but prior to encouraging high school students to pursue a career in engineering is crucial in building a strong foundation for a successful future nation. A report from the US National Academy of Engineering ${ }^{30}$ says that encouraging young people to make a difference in the world through an engineering career is more likely to attract them than emphasizing the challenge of math and science skills.

It is clear that there is an urgent need for more Brazilian initiatives to strengthen and improve mathematics and science teaching in the levels of primary and secondary education, especially to enable students to climb up higher scores in international tests like PISA. However, we may accept, for the most part, that successful completion of high school is necessary, but not necessarily a sufficient requirement for successful entry into the universitylevel engineering courses.

Attitude and personality growth are occasionally recognized, although not usually in a formal manner. College entrance exams are usually confined to a evaluating the content knowledge, neither considering skills nor attitudes that may generally influence the successful completion of the undergraduate studies or engineering career. However, we believe that high school students with the highest awareness of engineering tend to perceive the profession as a more creative and interesting profession to pursue.

The value of using surveys of engineering attitudes to help institutions evaluate their freshman engineering programs has been documented. However, this high school engineering attitudes survey succeeded in assessing students' perceptions of the engineering profession and engineers in a heterogeneous high school audience. Besides helping us understand that students' attitudes towards engineering are not significantly affected by their engineering career choice, it may contribute to an understanding of why students exhibiting positive engineering attitudes are not choosing engineering. Results of the survey will also be used to help us answer questions related to the misconceptions about engineering that may lead some students to select other careers rather than engineering. 
Students' enjoyment of math and science had more than $20 \%$ difference in all six likert-scale options when comparing their intention to pursue engineering career or not. This corroborates to the well-known engineering need of a strong background in math and science, although authors believe that engineering also requires a strong inter-disciplinary base.

What we called the most negative attitude towards engineering shown in item 36 ("engineers do not need to know a lot about environmental, economy and politics issues") by adding "partially disagree" and "totally disagree" results (figure 5) for both groups is in fact, for this paper, a very positive result since the survey item had a negative effect. This means that almost all participants do know that it is important that an engineer is updated with environmental, economic and political issues, corroborating to the thought that not only technical skills, but professionalism, self-management skills, people skills, important building blocks to success in any career ${ }^{45}$.

According to Gordon ${ }^{16}$, it is doubtful that attitudes can be "taught" explicitly. It is certain, however, that they can be acquired as part of the individual's growth and maturation, and that they will be the result of many influencing factors. The individual's family traditions, values, and practices, early schooling (and, more important, the individual's teachers in those schools), peer pressures, religious groups, and governmental practices and procedures, all contribute to the developed attitudes that a high-school graduate brings to his first career position. However they may be acquired, modified, or developed, although influenced greatly by the role model offered by the teachers to the students. This reinforces the need for high school students to be more "comfortable" when they are called upon to perform real-world engineering. The high school system shall consider some of the characteristics of a real-world engineer to be applied to already existing subjects.

This quantitative survey, which was designed to provide a representative picture across the high school students' attitudes towards engineering and engineers, yielded positive results in terms of correlation factors. Results extracted from this research were similar to other published studies ${ }^{5,8,23}$ and valid inferences about high school population can be made from participants' answers to this survey. Regardless students' career choice - engineering or not overall students responses reported favorable attitudes towards engineering. The survey provided robust measures at the overall high school students' level as well as for age, gender, school, course or school year they are in. Therefore, findings from the quantitative survey show that engineering as a profession was viewed positively, no matter the students' career choice.

Besides research revealing that high school students do have a positive attitude towards engineering, this paper also aims to contribute to the issue on awareness of the "engineering real world" as an excellent way to increase youth interest in pursuing engineering careers. However, we can conclude from the quantitative survey that greater knowledge drives a more positive attitude to engineering. The findings suggest that in order to engage the high school public more effectively, overall awareness and knowledge of engineering needs to be increased.

Teachers concerned with improving the education and training of engineers have a challenge to use the tools of the latest technology not only to broaden the knowledge-base and to strengthen the acquired fundamental analytical skills of the engineers-to-be, but especially to develop methods to encourage and train the real engineers-to-be, the leaders-to-be, to be imaginative, creative, daring, and responsible ${ }^{16}$. 
Attitudes towards engineering revealed in the survey tended to reinforce that providing people with information about engineering improves and clarifies understanding of the scope and breadth of engineering and importantly, generates interest in the profession. Individual accomplishments, achievements, skills and attitudes towards engineering will surely contribute to better engineering graduates that truly understand their role as professionals to lead in the invention and production of new products which benefit society.

This research may have provided a baseline measure of high school attitudes towards engineering which can inform action plans to build engagement including the provision of a baseline data to measure and compare changes in high school students' attitudes and perceptions, over time. The overall research aims of this work achieved its goals to determine public attitudes of engineering and engineers; to explore, in depth, the reasons for such attitudes to engineering and engineers; to explore perceptions on how engineering impacts and contributes to society. A better understanding of the impact of high school students' attitudes toward engineers and engineering will surely have many other positive outcomes. Yet the impact of these attitudes still needs to be better identified and explored further, and compared to other existing studies. Research studies exploring other variables and also additional attitudinal issues are needed.

In future studies, results of this high school attitudinal instrument will also be compared to other survey to be applied to engineering undergraduate students. Our acknowledge of engineering attitudes' importance will help us enhance future work on identifying potential skilled pre-engineering candidates and also to encourage them in favor of choosing the right career path, preferably towards engineering. To have positive attitudes towards engineers and engineering is a good start for high school students to pursue the "engineering world".

Our overall impression of this research was that the content of the items and the general purpose of the survey make an important contribution to the field of engineering education, in which considerable efforts need to be put into attracting more prepared and motivated young people to engineering.

Revision of survey items is necessary, besides retesting and rephrasing. However, the attitudinal part of the survey seems to assess valid and predictive aspects of high school students' attitudes towards engineering. Even though there were no marked differences in the responses between high school students that consider taking engineering from and the ones that do not consider it, we believe that by knowing how positive or negative their attitudes towards engineering and engineers reveal themselves to be, we can contribute to the issue of enhancing pre-engineering concepts in high school. And also as a result, this survey will help to strengthen initiatives that can impact high school students' attitudes in a more positive manner in order to encourage more and more high school students to pursue a career in engineering.

\section{REFERENCES:}

1. ALLPORT, G. "Attitudes" in: A Handbook of Social Psychology, ed. C. Murchison. Worcester, MA: Clark University Press, 1935. pp. 789-844. 
2. BALL, A.G. et al. Identification and validation of a set of global competencies for engineering students. International Journal of Engineering Education- IJEE, 28 (1): 156-168, 2012.

3. BECKER, F.S. Why don't young people want to become engineers? Rational reasons for disappointing decisions. European Journal of Engineering Education, 35 (4): 349-366, 2010.

4. BESTERFIELD-SACRE, M. E, Atman, CJ and Shuman, LJ, (1995). How Freshman Attitudes Change in the First Year. ASEE Annual Conference Proceedings, Anaheim, CA, 1995.

5. BESTERFIELD-SACRE, M. et al. Changes in Freshman Engineers' Attitudes - A Cross Institutional Comparison - What Makes A Difference? Frontiers in Education Conference 1996 (1). FIE'96 Annual Conference Proceedings of. Salt Lake City, UT, November 1996. p.78-82.

6. BESTERFIELD-SACRE, M.E., MORENO, M., SHUMAN, L.J., and ATMAN, C.J. Gender and Ethnicity Differences in Freshmen Engineering Student Attitudes: A Cross-Institutional Study. Journal of Engineering Education, 90(4): 477-489, 2001.

7. BESTERFIELD-SACRE, M.E.; ATMAN, C.J.; SHUMAN, L.J, Characteristics of Freshman Engineering Students: Models for Determining Student Attrition and Success in Engineering. The Journal of Engineering Education, 86 (2), April 1997.

8. BESTERFIELD-SACRE, M.E.; ATMAN, C.J.; SHUMAN, L.J., Student Attitudes Assessment. The Journal of Engineering Education, 87 (2):133-141, April 1998.

9. BESTERFIELD-SACRE, M.E; ATMAN, C. J. (1994). Survey Design Methodology: Measuring Freshman Attitudes About Engineering. ASEE Annual Conference Proceedings, Edmonton, 1994. pp.236-242

10. BESTERFIELD-SACRE, M.E; ATMAN, C.J. Survey Design Methodology: Measuring Freshman Attitudes about Engineering. American Society for Engineering Education Conference Proceedings, June 1994, pp. 236-242.

11. BRAZIL. INEP - Instituto Nacional de Estudos e Pesquisas Educacionais Anísio Teixeira. Resultados PISA 2012. October, 2013.

12. DEPIERI, A.D; LOPES, R. D. Students' Perceptions of Skills Importance to Engineering. Active Learning in Engineering Education Workshop (ALE 2014), Caxias do Sul, RS, Brazil, Jan 2014. pp.

13.EAGLY, A. H.; CHAIKEN, S. 1998. "Attitude Structure and Function." In Handbook of Social Psychology, ed. D.T. Gilbert, Susan T. Fisk, and G. Lindsey. New York: McGowan-Hill. pp. 269-322

14. EVERGREEN, S.; GULliCKSON, A.; MANN, C.; WELCHET, W. EvaluATE Webinar: Developing \& Validating Survey Instruments. Western Michingan University, Colorado, 2011. Retrieved from: http://evaluate.org/events/may_2011_webinar.

15. FELDER, R.M et al. A Longitudinal Study of Engineering Student Performance and Retention. III. Gender Differences in Student Performance and Attitudes, Journal of Engineering Education, 84 (2): 151-174, 1995.

16. GORDON, B.M. What is an Engineer? European Society for Engineering Annual Conference. University of Erlangen-Nurnberg, August, 1984. 33p.

17. HILPERT, J. et al. Steps toward a sound measure of engineering student attitudes: Pittsburgh Engineering Attitudes Scale - Revised. 39th Frontiers in Education Conference Proceedings, San Antonio, TX, October 2009. pp.1-6.

18. HIRSCH, L. et al. J. High school attitudes to and knowledge about engineering. 33rd Annual ASEE/IEEE Frontiers of Education Conference Proceedings, v. 2. Boulder, CO, November, 2003. pp. F2A_7-F2A_12.

19. IEDI - Instituto de Estudos para o Desenvolvimento Industrial. (2010). Carta IEDI n. 424 - A Formação de Engenheiros no Brasil: Desafio ao Crescimento e à Inovação. São Paulo, SP, Brazil.

20. KARATAS, F.O.; MICKLOS, A.; BODNER, G. Sixth-grade Students' View of the Nature of Engineering and Images of Engineers. Journal of Sci Educ Technol, v. 20:123-135, 2011

21. KATEHI, L. P.B. Engineering in K-12 Education. Statement of Linda P.B. Katehi, Ph.D. Chancellor, University of California, U.S. House of Representatives. October, 2009. Retrieved from: http://gop.science.house.gov/Media/hearings/research09/oct22/Katehi.pdf.

22. KIMBERLIN, C.; WINTERSTEIN, A.G. Validity and Reliability of Measurement Instruments used in Research. Am J Health-Syst Pharm, v. 65: 2276-2284, December, 2008. 
23. MARSHALL, H.; McClYMONT, L; JOYCE, L. Public Attitudes to and Perceptions of Engineering and Engineers 2007- A study commissioned by The Royal Academy of Engineering and the Engineering and Technology Board. The Royal Academy of Engineering, UK, 2007.

24. McLEOD, S. A. (2009). Attitude Measurement. Retrieved from http://www.simplypsychology.org/attitudemeasurement.html.

25. MCTI - Ministério da Ciência, Tecnologia e Inovação. (2012). Brasil: Alunos matriculados e titulados nos cursos de mestrado e doutorado, ao final do ano, por grande área, 1998-2011. Coordenação-Geral de Indicadores (CGIN) - $\quad$ ASCAV/SEXEC $\quad-\quad$ MCTI. Retrieved from http://www.mct.gov.br/index.php/content/view/7755.

26. MENA, I. B., DIEFES-DUX, H.A. First-year engineering students' portrayal of engineering in a proposed museum exhibit for middle school students. Journal of Science Education and Technology, 21 (2):304-316, 2012.

27. METZ, S. It takes a village to change the perception of engineering, American Society for Engineering Education Annual Conference, Honolulu, Hawaii, 2007.

28. MEYERS, K.L.; OHLAND, M. \& SILLIMAN. How Self-Identification and Views of Engineering Change with time: a study of students and professionals. International Journal of Engineering Education, 28 (1):103$112,2012$.

29. MOLINA-GAUDO, P. et al. Perception and intention in relation to engineering: a gendered study. IEEE Transactions on Education, V. 53 (1):61-70, Feb, 2010.

30. NAE - The National Academies. How to attract Young peolpe to engineering: 'make a difference' message is key. ScienceDaily, $25 \quad$ Jun, $2008 . \quad$ Retrieved from: http://www.sciencedaily.com/releases/2008/06/080624145221.htm.

31. OECD (2011a). Education at a Glance 2011: OECD Indicators. OECD Publishing. Retrieved from: www.oecd.org/edu/eag2011.

32. OECD (2011b). Strong Performers and Successful Reformers in Education: Lessons from PISA for the United States. OECD Publishing. Retrieved from: www.oecd.org/pisa/46623978.pdf.

33. OECD (2013) - Brazil Country Notes: Results from PISA 2012. Retrieved from http://download.inep.gov.br/acoes_internacionais/pisa/resultados/2013/country_note_brazil_pisa2012.pdf

34. OECD (2014). PISA 2012 Key Facts - Full selection of indicators from PISA 2012 by EDUGPS Explore Data. Retrieved from http://gpseducation.oecd.org/Helpers/EIEPrint.

35. PORTER, RL; FULLER, H.; FELDER, R.M. College of Engineering Freshman: Success and Attitudes, Part LT. Working Paper, College of Engineering, North Carolina State University, 1996.

36. ROBBINSON, M. et al. Engineering Principles for High School Students. 29th ASEE Frontiers in Education Conference- FIE'99, San Juan, Puerto Rico, November 10-13, 1999. pp. 13a7-21.

37. ROBBINSON, M.; KENNY, B. Engineering literacy in high school students. Bulletin of Science, Technology \& Society, v. 23 (2):95-101, April 2003.

38. SALERNO et al. Tendências e Perspectivas da Engenharia no Brasil. Relatório EngenhariaData 2012, Observatório da Inovação e Competitividades (OIC), Universidade de São Paulo, Brazil, April,2013.

39. STANSBURRY, M. (2011). Ten skills every student should learn. E-school News, August 11th. Retrieved from http://www.eschoolnews.com/2011/08/11/ten-skills-every-student-should-learn/

40. STRACHOTA, E.; SCHMIDT, S.W; CONCEIÇÃO, S.C. The Development and Validation of a Survey Instrument for the Evaluation of Instructional Aids. Midwest Research-to-Practice Conference in Adult, Continuing, and Community Education, University of Missouri-St. Louis, St. Louis, MO, October 4-6, 2006.

41. TELLES, M. (2009). Brasil sofre com a falta de engenheiros: Área é considerada estratégica para o desenvolvimento do País. Revista Inovação em Pauta, n. 6:11-15, Rio de Janeiro: FINEP.

42. TOZZI, M.; TOZZI, A.R. (2011). Escassez de Engenheiros no Brasil: mito ou realidade? XXXIC Congresso Brasileiro de Educação em Engenharia - COBENGE, Blumenau, SC, Brazil. Retrived from http://www.abenge.org.br/CobengeAnteriores/2011/sessoestec/art1579.pdf.

43. VAUGHAN, G ; HOGG, M. Social Psychology. 4 ed. London: Prentice-Hall. 2005, pp.150.

44. WALONICK, D.S. Steps in Designing a Survey. Copyright (C) 2014 StatPac Inc. Retrieved from http://www.statpac.com/survey-design-guidelines.htm. 
45. MOIN, R.; SMRUTIHARA, B. Soft skills in status quo. International Journal of Physical and Social Sciences (IJPSS), vol. 2 (5): 212-225, 2012.

46. SALERNO et al. (2014). Tendências e Perspectivas da Engenharia no Brasil. Relatório EngenhariaData 2013. Workshop, Observatório da Inovação e Competitividades (OIC), Universidade de São Paulo, Brazil, March 14. 